\title{
Relationship between ganglioside expression and anti-cancer effects of a plant-derived antibody in breast cancer cells
}

\author{
Won Seok Ju· Ilchan Song • Se-Ra Park • Sang Young Seo • Jin Hyoung Cho - Sung-Hun Min • Dae-Heon Kim • \\ Ji-Su Kim • Sun-Uk Kim • Soon Ju Park • Kisung Ko • Young-Kug Choo
}

Received: 29 August 2019 / Revised: 3 September 2019 / Accepted: 4 September 2019

(c) Korean Society for Plant Biotechnology

\begin{abstract}
Production of therapeutic monoclonal antibodies (mAbs) using a plant platform has been considered an alternative to the mammalian cell-based production system. A plant-derived $\mathrm{mAb} \mathrm{CO} 17-1 \mathrm{AK}\left(\mathrm{mAb} \mathrm{b}^{\mathrm{P}} \mathrm{COK}\right)$ can specifically bind to various types of cancer cell lines. The target protein of $\mathrm{mAb} \mathrm{b}^{\mathrm{P}} \mathrm{COK}$ is the epithelial cell adhesion molecule (EpCAM) highly expressed in human epithelial cancer cells, including breast and colorectal cancer cells. It has been hypothesized that its overexpression supports tumor growth and metastasis. A ganglioside is extended well beyond the surfaces of the various cell membranes and has roles in cell growth, inflammation, differentiation, and carcinogenesis. However, the regulation of EpCAM gene expression in breast cancers and the role of gangliosides in oncogenesis are
\end{abstract}

W. S. Ju - S. Y. Seo - J. H. Cho - S. J. Park • Y.-K. Choo Department of Biological science, College of Natural Sciences, Wonkwang University, 460, Iksan-daero, Iksan-si, Jeollabuk-do 54538 , Republic of Korea

I. Song $\cdot$ S.-R. Park $\cdot$ K. Ko

Department of Medicine, Medical Research Institute, College of Medicine, Chung-Ang University, 84, Heukseok-ro, Dongjak-gu, Seoul 06974, Republic of Korea

S.-H. Min

Center of Reproductive Medicine, Good Moonhwa Hospital, 119, Beomil-ro, Dong-gu, Busan 48735, Republic of Korea

D.-H. Kim

Department of Biology, Sunchon National University, 235, Jungang-ro, Sunchon-si, Jeollanam-do 57922, Republic of Korea

J.-S. Kim • S.-U. Kim

National Primate Research Center, Korea Research Institute of Bioscience and Biotechnology, 30, Yeonggudanji-ro,

Ochang-eup, Cheongwon-gu, Cheongju-si, Chungcheongbuk-do 28116, Republic of Korea

J. H. Cho • Y.-K. Choo $(\bowtie)$

Institute for Glycoscience, Wonkwang University, 460,

Iksan-daero, Iksan-si, Jeollabuk-do 54538, Republic of Korea e-mail: ykchoo@wku.ac.kr unclear. Here, the purpose of this study was to determine the effects of $\mathrm{mAb} \mathrm{b}^{\mathrm{P}} \mathrm{COK}$ on human breast cancer cell proliferation, apoptosis, and ganglioside expression patterns. Our results show that treatment with $\mathrm{mAb} \mathrm{P}^{\mathrm{P}} \mathrm{COK}$ suppressed the growth of breast cancer cells and induced apoptotic cell death. It also upregulated the expression of metastasis-related gangliosides in breast cancer cells. Thus, treatment with $\mathrm{mAb} \mathrm{b}^{\mathrm{P}} \mathrm{COK}$ may have chemo-preventive therapeutic effects against human breast cancer.

Keywords Anti-cancer, Apoptosis, Breast carcinoma, Ganglioside, Plant-derived antibody CO17-1A

\section{Introduction}

Breast cancer is the most common cancer affecting women, with an estimated 1.38 million new cases reported per year worldwide (Eccles et al. 2013). In addition, the worldwide incidence rate of breast cancer has increased steadily (Kim et al. 2010). Despite advances in therapeutic treatments, about $40 \%$ of patients still suffer from this disease mainly due to metastasis (Siegel et al. 2012).

Epithelial cell adhesion molecule (EpCAM), also known as KS1/4, gp40, GA733-2, 17-1A, and TROP-1, is one of the most well-known target antigenic proteins of human cancers (Baeuerle and Gires 2007; Strnad et al. 1989; Trizpis et al. 2007). It is a $40 \mathrm{kDa}$ type I membrane glycoprotein that serves as a homotypic adhesion molecule extravagantly expressed in primary tumors (Balzar et al. 1999; Lintvinov et al. 1994) and up-regulated on actively proliferating epithelial tissues, during adult liver regeneration, and on many epithelial cell-derived carcinoma (Schnell et al. 2013; de Boer et al. 1999). It is closely related to metastasis of many epithelial tumors, particularly of adenocarcinoma (Spizzo et al. 2011; Went et al. 2004). EpCAM is highly expressed in cancer 
stem cells of pancreatic and colorectal adenocarcinomas as well as breast carcinomas (Dalerba et al. 2007; Li et al. 2007; Al-Hajj et al. 2003).

Various anti-EpCAM antibodies have been recently investigated in clinical studies as immunotherapeutic agents that mediate antibody-dependent cell-mediated cytotoxicity (ADCC) and induce complement-mediated cytotoxicity (CDC) (Münz et al. 2010; Moldenhauer et al. 2012). Despite the demand for therapeutic mAbs, current mammalian cell-based production systems provide only limited amounts (Brodzik et al. 2006). Plants offer several advantages for $\mathrm{mAb}$ production such as absence of contamination by pathogens affecting humans and relatively low cost of cultivation (Gomord et al. 2004; Ma et al. 2003). Therefore, these plant systems have been regarded as alternatives for recombinant $\mathrm{mAb}$ production (Daniell et al. 2001).

Meanwhile, recombinant anti-colorectal cancer mAb CO171A has been produced in tobacco plants with stable gene insertion through seedlings (Koprowski and Yusibov 2001; Verch et al. 1998). The plant-derived $\mathrm{mAb}\left(\mathrm{mAb} \mathrm{b}^{\mathrm{P}}\right) \mathrm{CO} 17-1 \mathrm{~A}$ can uniquely recognize and bind to various colorectal carcinoma and effectively inhibit xenotransplanted colorectal cancer cell tumor growth in nude mice to the same extent as does the mammalian mAb CO17-1A (Ko et al. 2005).

Gangliosides are a subclass of acidic glycosphingolipids carrying one or more sialic acid residues in the carbohydrate moiety (Todeschini and Hakomori 2008). They can regulate signal transduction pathways involved in cell-cell adhesion, differentiation, cell proliferation, and recognition (Furukawa 1996; Julien et al. 2013; Ju et al. 2005; Lee et al. 2010). Sialyated glycosphingolipids from the ganglio-series are normally classified into four series from 0 - to c-series and shed actively into the tumor microenviroment (Svennerholm 1980; Kudo et al. 2003). Human normal tissues express various gangliosides of 0 - and a-series (Ji et al. 2000; Yamashita et al. 1999) and its complex expression is increased under manifold pathological disorders (Ariga et al. 2008), immune diseases (Shahrizaila and Yuki 2011), and cancer (Bobowski et al. 2012). GD3 has been considered a cell death effector because of its ability to interact with mitochondria-mediated apoptosome activation and subsequent apoptosis based on death ligands (Paris et al. 2002). In support, GD3 can induce apoptosis of human colorectal cancer cells and human breast cancer cells (Basu et al. 2004). It has been reported that GD1b can induce apoptosis of human breast carcinoma SKBR3 cells (Ma et al. 2004) and GD1a has an important role in the growth and differentiation of tissues in carcinogenesis (David and Michael 2005). However, the underlying role of GD1b in inducing apoptosis of tumor cells still remains unclear. In breast cancer, the effects of $\mathrm{mAb} \mathrm{b}^{\mathrm{P}} \mathrm{CO} 17-1 \mathrm{~A}$ on expression patterns of ganglioside and apoptotic cell death have not yet been reported.

Thus, this research is designed to determine the anticancer effects of $\mathrm{mAb} \mathrm{b}^{\mathrm{P}} \mathrm{COK}$ on cancer cell growth, proliferation, apoptosis, and the pattern of gangliosides in breast carcinoma. In the results, we showed that anti-colorectal cancer $\mathrm{mAb}^{\mathrm{P}} \mathrm{COK}$ not only suppress and inhibit cancer cell growth and proliferation but also induce apoptosis in breast cancer cells. For the first time, we found that the target gangliosides, such as GD1a and GM1, were expressed in human breast cancer after treatment with $\mathrm{mAb} \mathrm{b}^{\mathrm{P}} \mathrm{COK}$.

\section{Material and Methods}

Preparation of plant material

The cDNA fragments encoding a heavy chain (HC) fused to the ER retention signal KDEL (HCK) and light chain (LC) of anti-colorectal cancer $\mathrm{mAb}$ CO17-1AK have been successfully cloned to a $\mathrm{pBI}$ COK vector (Fig. 1A) (Song et al. 2018). Agrobacterium-mediated plant transformation was conducted to generate transgenic Arabidopsis lines expressing mAb CO17-1AK as previously described (Paris et al. 2002). Transgenic seedlings were selected on MS media containing kanamycin $(50 \mu \mathrm{g} / \mathrm{mL})$, transplanted, and grown in fresh soil.

Purification of anti-colorectal cancer monoclonal antibody

Transgenic Arabidopsis leaves (200 grams) were freshly harvested and homogenized in an $800 \mathrm{~mL}$ extraction buffer (37.5 mM Tris- $\mathrm{HCl} \mathrm{pH}$ 7.5, $50 \mathrm{mM} \mathrm{NaCl}, 15 \mathrm{mM}$ EDTA, $75 \mathrm{mM}$ sodium citrate, $0.2 \%$ sodium thiosulfate) using a HR2094 grinder (Philips, Seoul, Korea). The homogenized leaf extract was centrifuged at $8,800 \times g$ for $30 \mathrm{~min}$ at $4^{\circ} \mathrm{C}$ and the supernatant was filtered through a Miracloth (Biosciences, La Jolla, CA, USA). After centrifugation at $10,200 \times g$ for $30 \mathrm{~min}$, supernatants were filtered through a Miracloth. The filtered solution was adjusted to $\mathrm{pH} 7.0$ with $3 \mathrm{M}$ Tris- $\mathrm{HCl}$ and mixed with ammonium sulfate to a concentration up to $8 \%$. After centrifugation at $8,800 \times$ $g$ for $30 \mathrm{~min}$ at $4^{\circ} \mathrm{C}$ the supernatant was mixed with ammonium sulfate to a concentration of $24 \%$ and incubated overnight at $4^{\circ} \mathrm{C}$. After centrifugation, the pellet was resuspended in one-twelfth of the volume of the starting extraction buffer. Then, the solution was centrifuged. The 
A

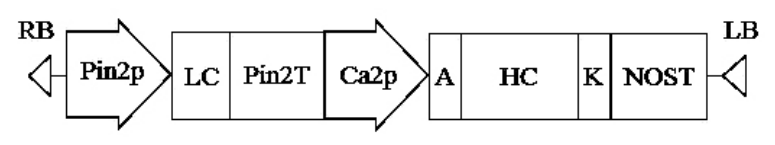

pBI COK

B
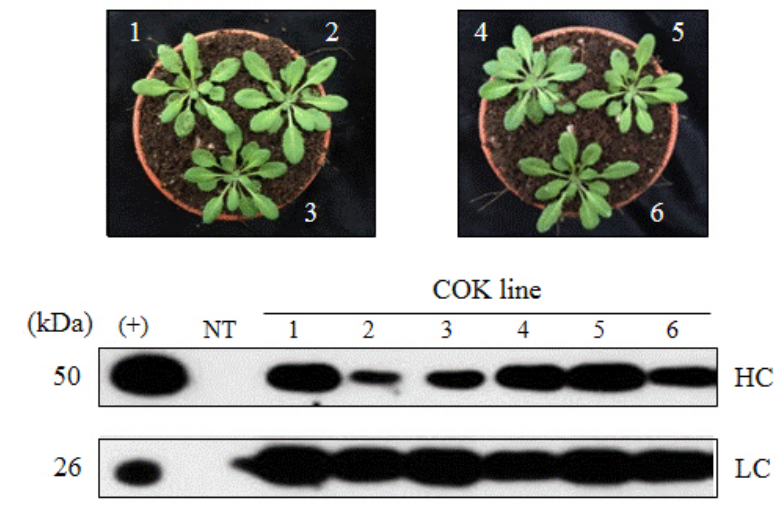

C

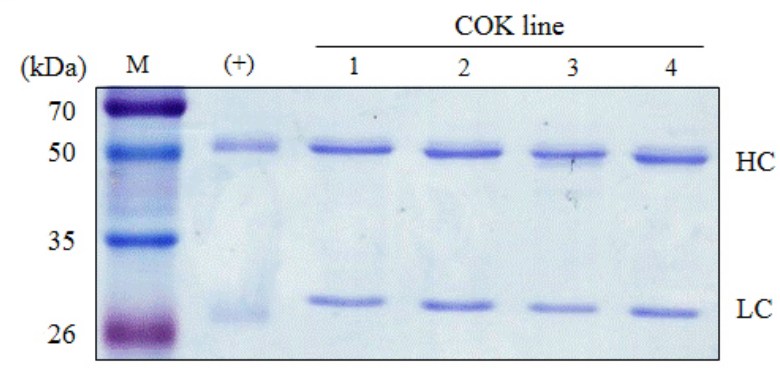

Fig. 1 Expression and purification of $\mathrm{mAb} \mathrm{COK}$ from the transgenic Arabidopsis plant

(A) Schematic diagram of a plant expression cassette for $\mathrm{mAb}$ COK HC and LC for the transformation of Arabidopsis plant. Pin2p, promotor of Pin2 gene from potato; and Ca2p, cauliflower mosaic virus $35 \mathrm{~S}$ promotor; $\mathrm{K}$, KDEL, the 3 ' endoplasmic reticulum retention motif; $\mathrm{A}$, an alfalfa mosaic virus untranslated leader sequence of RNA4; Pin2T, terminator of Pin2 gene from potato; NOST, terminator of nopaline synthase gene. (B) $T_{1}$ transformed shoots survived under kanamycin selection were transplanted to a soil pot and grown in the growth chamber (upper). Western blot analysis of $\mathrm{T}_{1}$ generation plants to confirm $\mathrm{HC}$ and $\mathrm{LC}$ gene expression. $\mathrm{HC}$ and $\mathrm{LC}$ were detected with horseradish peroxidase-conjugated goat anti-murine IgG Fc- or IgG F( $\left.\mathrm{ab}^{\prime}\right)_{2}$-specific antibodies, respectively (lower). $(+)$, positive control: mammalian-derived anti-EpCAM mAb; NT, non-transgenic plant; Lane 3-8, $T_{1}$ transformants expressing anti-colorectal cancer mAb COK. (C) SDS-PAGE analysis of purified samples from transgenic Arabidopsis expressing mAb COK (lanes 1, 2, 3, and 4). M, protein marker; $(+)$, anti-EpCAM $\mathrm{mAb}$; Lanes 3-6, purified after protein A affinity purification process

supernatant was filtered through a Miracloth and applied to an affinity column (GE Healthcare, Piscataway, NJ, USA) as described at manufacturer's instruments. The eluted
mAb COK protein was dialyzed with $1 \times$ PBS $(\mathrm{pH} 7.4)$ twice at $4^{\circ} \mathrm{C}$ for $3 \mathrm{~h}$. Protein concentration was determined with a nano-drop (Biotek, Highland, VT). For further study, the dialyzed $\mathrm{mAb} \mathrm{COK}$ was stored at $-80^{\circ} \mathrm{C}$ deep freezer.

\section{Cell culture}

Human breast cancer MCF-7 cell was kindly provided from the Korean Cell Line Bank (KCLB, Seoul, Korea) and maintained in RPMI-1640 medium supplemented with $10 \%(\mathrm{v} / \mathrm{v})$ fetal bovine serum (FBS), $100 \mathrm{U} / \mathrm{mL}$ each of penicillin and streptomycin, at $37^{\circ} \mathrm{C}$ in $5 \% \mathrm{CO}_{2}$ incubator. RAW264.7 cells were also provided from the KCLB and maintained in Dullbecco's Modified Eagle's Medium (DMEM) supplemented with $10 \%(\mathrm{v} / \mathrm{v})$ FBS, $100 \mathrm{U} / \mathrm{mL}$ each of penicillin and streptomycin, at $37^{\circ} \mathrm{C}$ in $5 \% \mathrm{CO}_{2}$ incubator.

\section{Cell viability (MTS) assay}

CellTiter $96^{\circledR}$ Aqueous One Solution Cell Proliferation Assay (MTS) was conducted to investigate the effects of the $\mathrm{mAb}$ COK on cell viability (Promega, Beijing, China) as described at manufacturer's recommendations. For 24 h, MCF-7 cells were seeded into a 96-well plate and treated with $\mathrm{mAb}$ COK $(0-16.0 \mu \mathrm{g} / \mathrm{mL})$, RAW264.7 cells, or RAW264.7 cells and $\mathrm{mAb}$ COK $(0-16.0 \mu \mathrm{g} / \mathrm{mL})$ for $8 \mathrm{~h}$. Then MTS reagent $(20 \mu \mathrm{L})$ was applied to each well followed by incubation in $5 \% \mathrm{CO}_{2}$ humidified air at $37^{\circ} \mathrm{C}$ for $3 \mathrm{~h}$. The absorbance at $490 \mathrm{~nm}$ was recorded using a TECAN Sunrise ${ }^{\mathrm{TM}}$ absorbance reader (Tecan Group Ltd, Männedorf, Switzerland).

Immunocytochemistry

To detect specific ganglioside GDla, MCF-7 human breast cancer cells were blocked $5 \%(\mathrm{v} / \mathrm{v})$ bovine serum albumin in PBS (BSA/PBS) and incubated with $\mathrm{mAb} \mathrm{COK}$ at $4^{\circ} \mathrm{C}$ overnight. Probed cells were reacted with a fluorescenceconjugated secondary antibody and FITC-conjugated antimurine IgG for the $\mathrm{mAb} C \mathrm{COK}$ at a 1:500 dilutions. Stained cells were visualized using a confocal microscope (Carl Zeiss Gmbh, Jena, Germany).

Immunoblot analysis

Leaves of $T_{1}$ plants were sampled for immunoblot analysis to confirm the expression of $\mathrm{mAb} \mathrm{HC}$ and LC proteins. The leaf samples $(50 \mathrm{mg})$ were frozen in liquid nitrogen and crushed immediately, and then suspended in $100 \mu \mathrm{L}$ of sample buffer ( $1 \mathrm{M}$ Tris- $\mathrm{HCl}, 50 \%$ glycerol, $10 \% \mathrm{SDS}$, 
5\% 2-mercaptoethanol, $0.1 \%$ bromophenol blue). The samples were boiled for $10 \mathrm{~min}$ and cooled on ice. Total soluble proteins were separated by $10 \%$ SDS-PAGE and electrotransferred to a nitrocellulose membrane (Millipore, Billerica, MA, USA). The membranes were incubated with $5 \%$ skimmed milk (Sigma, St. Louis, MO, USA) overnight at $4^{\circ} \mathrm{C}$. The membranes were incubated with HRP-conjugated goat anti-mouse $\operatorname{IgG~Fc\gamma }$ and anti-mouse $\operatorname{IgG~F(ab)'2~to~}$ recognize the $\mathrm{HC}$ and $\mathrm{LC}$ of $\mathrm{mAb} \mathrm{COK}$, respectively. After washing three times with $1 \times$ PBST buffer $(1 \times$ PBS plus $0.5 \%$ Tween- $20, \mathrm{v} / \mathrm{v}, 10 \mathrm{~min}$ for each wash), proteins were detected with using SuperSignal West Pico Chemiluminescent Substrate (Thermo Scientific, Rockford, IL, USA) and X-ray film (Fuji, Tokyo, Japan). Leaves of wild type Arabidopsis were used as a negative control.

To investigate diverse protein expression of MCF-7 breast cancer cells by immunoblotting, whole-cell lysates were prepared using a radioimmunoprecipitation assay (RIPA) buffer (Sigma) containing mammalian protease inhibitor cocktail (Sigma, St. Louis, MO, USA). Protein concentrations were determined using the Bradford method. Extracted proteins samples $(40 \mu \mathrm{g})$ were separated by $10 \%$ or $12 \%$ SDS-PAGE and then transferred to membranes, which were incubated overnight at $4^{\circ} \mathrm{C}$ with specific antibodies. The protein bands were visualized after horseradish peroxidaseconjugated secondary antibody incubation, using a Priece ECL Western Blotting Substrate Plus (Thermo scientific, Rockford, IL, USA).

Extraction and purification of gangliosides

Gangliosides were extracted from cells as previously described (Lee et al. 2007). Total lipids were extracted with chloroform/ methanol $(1: 1, \mathrm{v} / \mathrm{v})$. Subsequently, neutral lipids were filtered off with $20 \mathrm{~mL}$ of chloroform $/$ methanol/ $\mathrm{H}_{2} \mathrm{O}(15: 30: 4, \mathrm{v} / \mathrm{v})$ by applying DEAE Sephadex A25 column (Sigma), and then acidic lipids were extracted with $15 \mathrm{~mL}$ chloroform/ methanol/0.8 M sodium acetate (15:30:4, v/v). The eluted samples were dried with $\mathrm{N}_{2}$ gas at $30^{\circ} \mathrm{C}$, then dissolved in chloroform/methanol $(1: 1, \mathrm{v} / \mathrm{v})$, neutralized with $12 \mathrm{~N}$ $\mathrm{NH}_{4} \mathrm{OH}$ overnight at room temperature. After the neutralized samples were dried again with $\mathrm{N}_{2}$ gas at $30^{\circ} \mathrm{C}$, dried samples were dissolved in distilled water, and the salt was removed with a Sep-Pak C18 cartridge (Millipore) to obtain gangliosides. Finally, eluted gangliosides were dried with $\mathrm{N}_{2}$ gas at $30^{\circ} \mathrm{C}$ for $4 \mathrm{~h}$. Dried samples were stored at $-80^{\circ} \mathrm{C}$ until the next use.
High-performance thin-layer chromatography (HPTLC)

HPTLC analysis was performed to analyze ganglioside profile, as described previously (Lee et al. 2007). The eluted gangliosides with chloroform/methanol $(1: 1, \mathrm{v} / \mathrm{v})$ were run on HPTLC plates and the plates developed with chloroform $/$ methanol $/ 0.25 \% \mathrm{CaCl}_{2} \cdot \mathrm{H}_{2} \mathrm{O}(50: 40: 10, \mathrm{v} / \mathrm{v})$. The developed gangliosides were stained with resorcinol solution $(\mathrm{HCl}$, $0.1 \mathrm{M} \mathrm{CuSO}_{4} \cdot 5 \mathrm{H}_{2} \mathrm{O}$, resorcinol, distilled warter). Monosialoganglioside Mixture (Matreya LLC, State College, PA, USA) and disialoganglioside Mixture (Matreya LLC) were used as standard markers for individual ganglioside species.

Data analysis

Results were presented as mean \pm standard deviation of at least three independent experiments performed in triplicates. Data were analyzed for statistical significance using oneway analysis of variance. $P$-value of less than 0.05 was considered statistically significant.

\section{Results}

Purification of plant-derived monoclonal antibody CO17-1AK (mAb $\left.{ }^{\mathrm{P}} \mathrm{COK}\right)$ from transgenic Arabidopsis

Arabidopsis transgenic plants were obtained by Agrobacterium-mediated transformation with a plant expression vector carrying the cDNA encoding the heavy chain $(\mathrm{HC})$ and light chain (LC) of mAb CO17-1AK (Fig. 1A, B). The presence of $\mathrm{HC}$ and $\mathrm{LC}$ genes was confirmed in genomic DNA isolated from transgenic plants by reverse transcription PCR (data not shown). Immunoblot analysis confirmed the expression of both HC $(50 \mathrm{kDa})$ and $\mathrm{LC}(26 \mathrm{kDa})$ of $\mathrm{mAb} \mathrm{b}^{\mathrm{P}}$ $\mathrm{COK}$ in transgenic plants. The binding activity of $\mathrm{mAb}$ COK to human colon cancer cells was confirmed by Cell ELISA (Ko et al. 2005). In SDS-PAGE analysis, the purified samples fraction \#1, 2, 3, and 4 from transgenic lines showed two major bands (50 and $26 \mathrm{kDa}$, respectively) similar to anti-EpCAM mAb (Fig. 1C).

Effect of $\mathrm{mAb} \mathrm{COK}$ on the viability of MCF-7 breast cancer cells

Increasing immuno-stimulatory activation of macrophages targeting cancer has been recognized as a new immunotherapeutic target (Klimp et al. 2002), in particular activated macrophages are well known to act as mediator of tumor 
$\mathbf{A}$
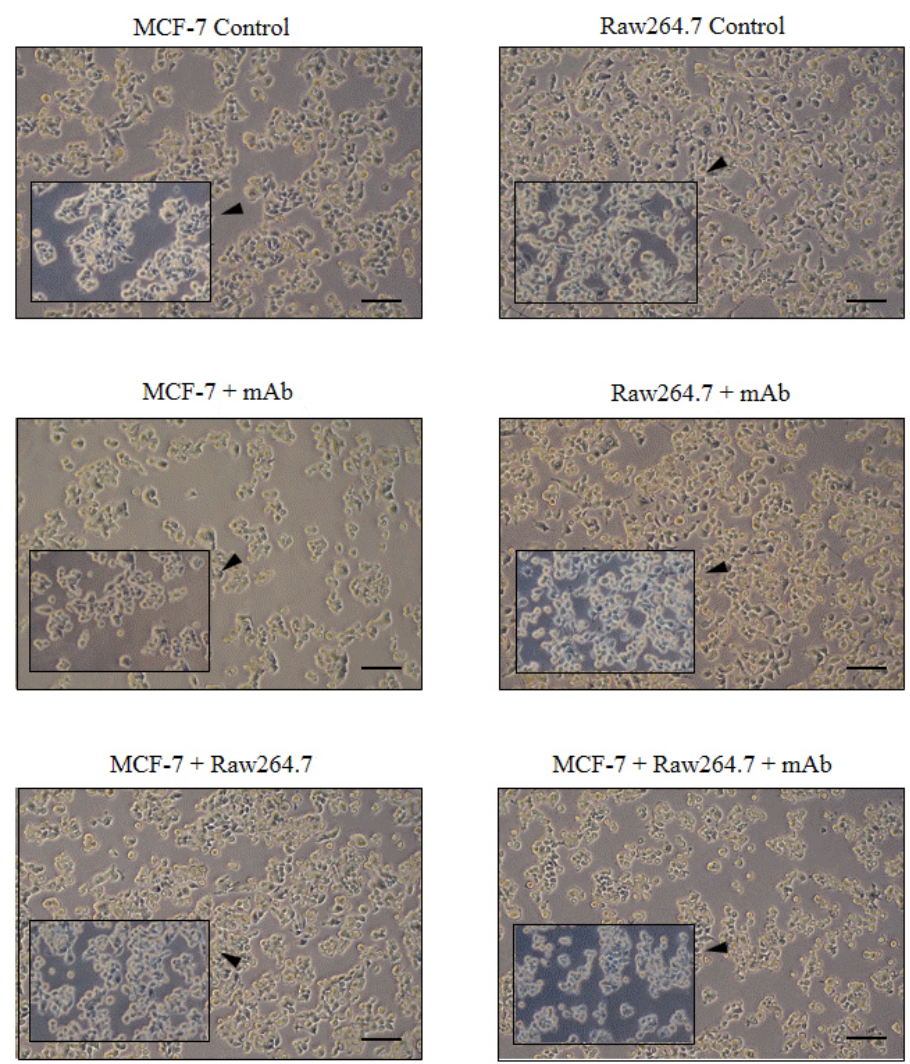

B

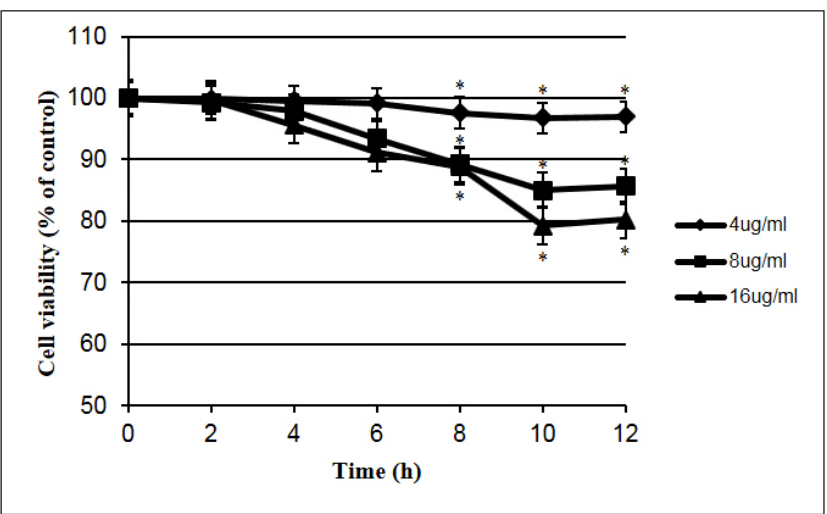

C

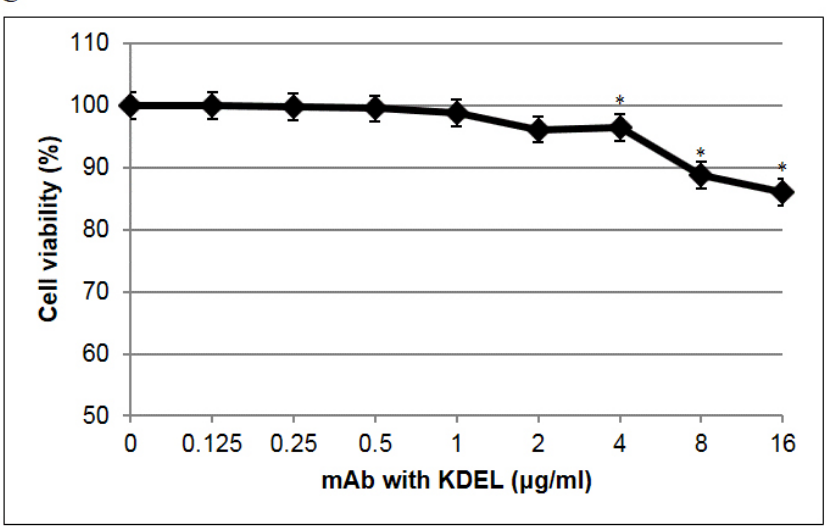

Fig. 2 Cytotoxicity of mAb COK to MCF-7 breast cancer cells

Morphological changes in MCF-7 human breast cancer cells treated with both mAb COK and RAW264.7 cells. (A) Morphology of MCF-7 human breast cancer cells. (B) Viability of MCF-7 human breast cancer cells treated with mAb COK $(0,0.125,0.25,0.5$, 1.0, 2.0, 4.0, 8.0, $16.0 \mathrm{\mu g} / \mathrm{mL}$ ) and RAW264.7 cells for 8 hours. The treatment ratio of MCF-7 human breast cancer cells to RAW264.7 cells was 1:10. (C) MTS assay for cell viability was performed with increasing concentrations of mAb COK and different time courses. Values are represented as mean \pm standard deviation (SD) of at least three independent experiments. ${ }^{*} P<0.05$. Scale bar, $100 \mu \mathrm{m}$

cell death (Keller et al. 1990). To assess whether immunoreaction of mAb COK with RAW264.7 cells is affected to cancer cell growth, the inhibitory effect of mAb COK on MCF-7 breast cacner cell growth was performed and the inhibition of cell proliferation by the immunoreaction of both treatments was observed (Fig. 2A). As shown in
Figure 2A, no significant change of cell growth was confirmed for MCF-7 breast cancer cell treated with RAW264.7 cell. However, the growth of the MCF-7 breast cancer was remarkably decreased in the $\mathrm{mAb} \mathrm{COK}$ treatment group. It is indicated that $\mathrm{mAb} C \mathrm{COK}$ induces immune function activity in RAW264.7 cells against breast cancer cells. 
A

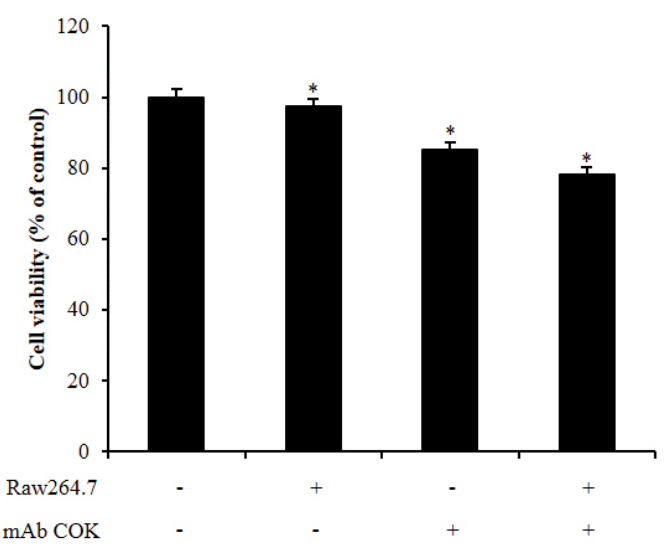

B

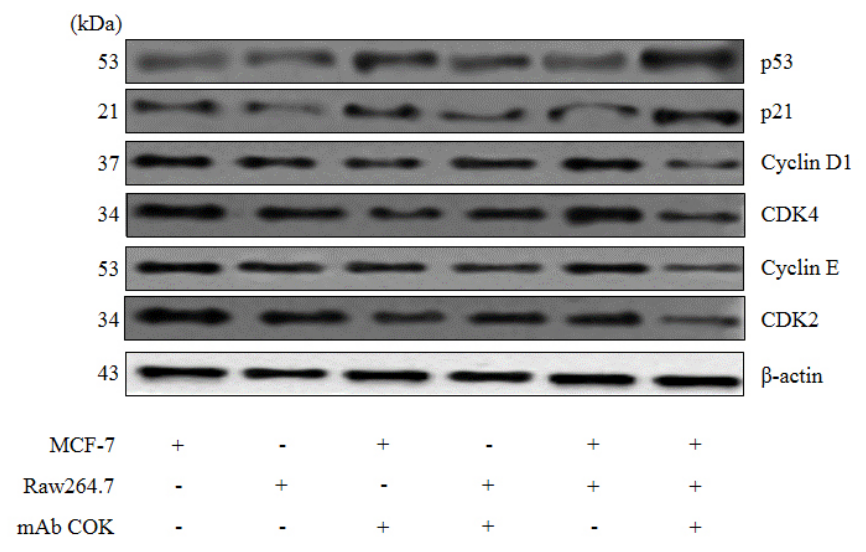

C
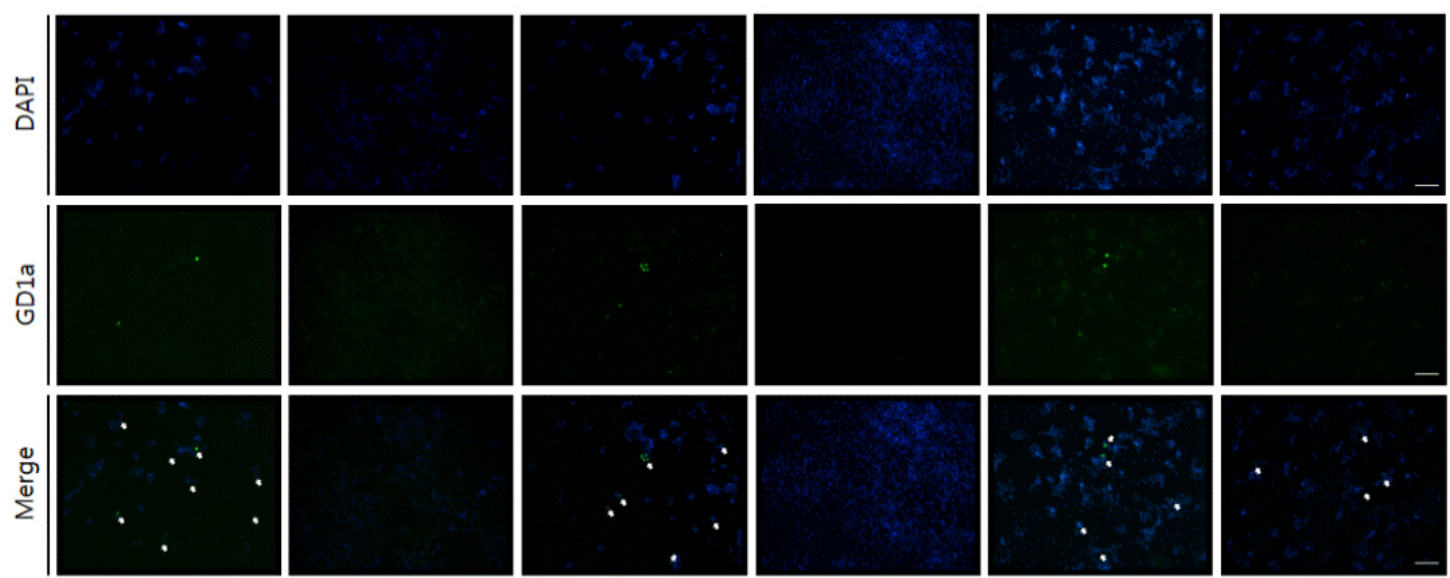

MCF-7

Raw264.7

mAb COK

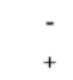

Fig. 3 Effect of mAb COK on cell proliferation and expression level of cell cycle proteins in MCF-7 cancer cells (A) MCF-7 cells were seeded into plates at a cell density of $5.0 \times 10^{4}$ cells/well and treated with mAb COK and RAW264.7 cells for 8 hours and cell viability was determined by 96-well MTS assay. (B) Levels of p53, p21, and G1 to S phase-related proteins in MCF-7 human breast cancer cells were examined by western blot analysis using specific antibodies. (C) Changes of ganglioside expression in cancer cells were stained by double immunofluorescence. Treatment with anti-EpCAM mAb $(10 \mu \mathrm{g} / \mathrm{mL})$ for $8 \mathrm{~h}$. Values are represented as mean $\pm \mathrm{SD}$ of at least three independent experiments. ${ }^{*} P<0.05$. $\beta$-actin was used to indicate the amount of loading protein

Then, MTS assay was performed to investigate the effect of mAb COK on the viability of breast cancer cell line (Fig. 2B, C). First, the concentration of $\mathrm{mAb} \mathrm{COK}$ required to obtain a significant inhibitory effect on the viability of MCF-7 breast cancer cells was determined by incubating the cells with 0 to $16.0 \mu \mathrm{g} / \mathrm{mL}$ of $\mathrm{mAb} \mathrm{COK}$. Its $\mathrm{IC}_{50}$ value for inhibiting the viability of MCF-7 human breast cancer cells was $10.0 \mu \mathrm{g} / \mathrm{mL}$. Significant apoptotic effects on MCF-7 breast cancer cells were observed at a concentration of 8.0 to $16.0 \mu \mathrm{g} / \mathrm{mL}$. Results showed that the viability of MCF-7 breast cancer cells was decreased by $\mathrm{mAb} \mathrm{COK}$ in a concentration- and time-dependent manner. To observe morphological changes, MCF-7 cells were treated with $4.0-16.0 \mu \mathrm{g} / \mathrm{mL}$ of $\mathrm{mAb} \mathrm{COK}$ for $8 \mathrm{~h}$.
Results showed that cell size was decreased after treatment with mAb COK. After treatment, mAb COK, MCF-7 breast cancer cells steadily adopted a little round shape.

Effect of $\mathrm{mAb} \mathrm{COK}$ on the proliferation of MCF-7 breast cancer cells

MCF-7 human breast cancer cells were treated with $\mathrm{mAb}$ COK, RAW264.7 cells, or RAW264.7 cells and mAb $\mathrm{COK}$ for $8 \mathrm{~h}$ to determine whether mAb COK inhibit the proliferation of MCF-7 breast cancer. Results showed that treatment with $\mathrm{mAb} \mathrm{COK}$ resulted in reduced cell proliferation (Fig. 3A). We investigated the possible mechanisms involved in the inhibitory effect of $\mathrm{mAb} C \mathrm{COK}$ on the 


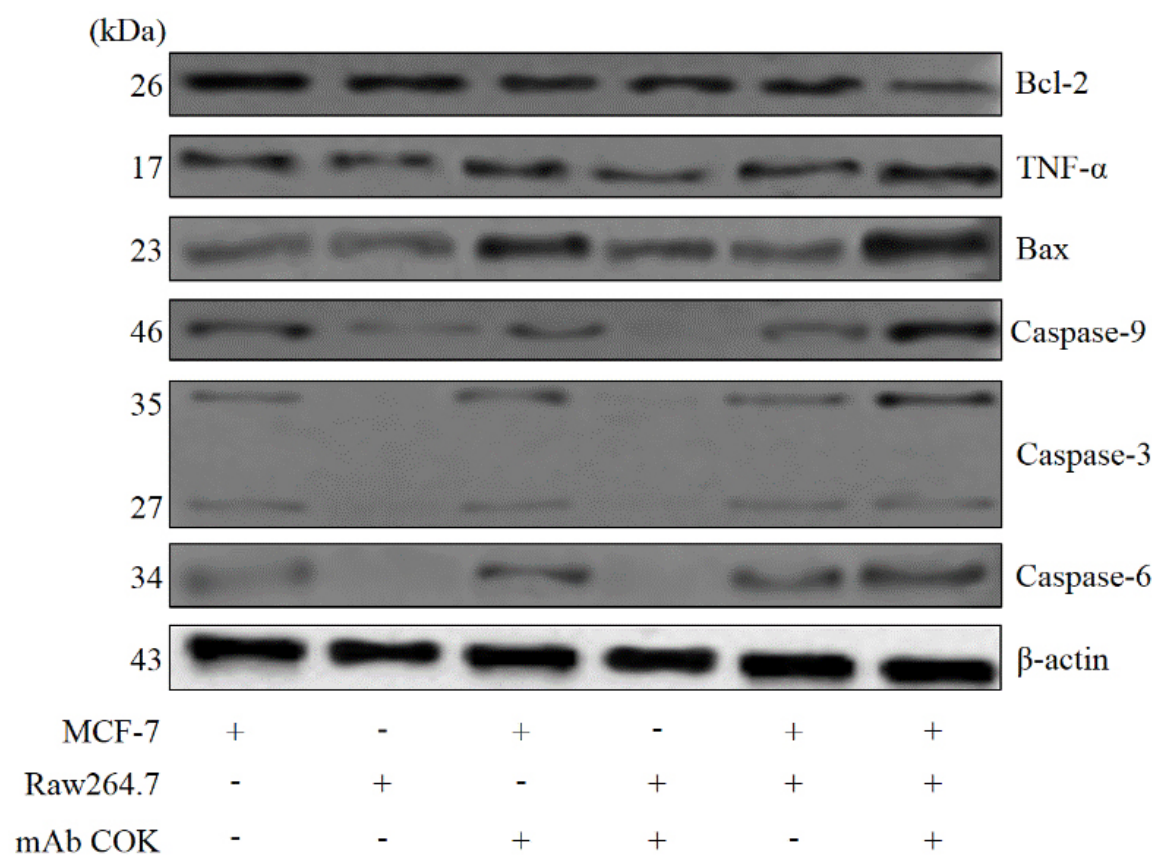

Fig. 4 Effect of $m A b^{P}$ COK on the regulation of apoptosis in MCF-7 cells

Apoptotic regulatory protein expression in MCF-7 human breast cancer cells treated with both treatments. The level of anti-apoptotic protein and pro-apoptotic proteins were analyzed by immunoblot analysis using specific antibodies. $\beta$-actin was used to indicate the amount of loading protein. This experiment was repeated three times with similar results

proliferation of MCF-7 human breast cancer cells. Since cellular proliferation depends on the progression of the cell cycle, the effect of plant-derived mAb COK on cell cyclerelated protein expression was determined by immunoblot analysis (Fig. 3B). MCF-7 cells treated with both treatments showed that a significant increase in $\mathrm{p} 53$ and $\mathrm{p} 21$ expression but reduction in the expression of proteins related with cell cycle control. These results suggest that plant-derived $\mathrm{mAb}$ COK can inhibit the growth of MCF-7 human breast cancer cells by inducing p53 and p21 while blocking the specific phase in cell cycle. In addition, the binding of $\mathrm{mAb}^{\mathrm{P}}$ COK to GA733-2 antigen was determined by immunofluorescence. As shown in Figure 3C, the expression of ganglioside GD1a was found to be significantly decreased in MCF-7 human breast cancer cells treated with $\mathrm{mAb}$ COK and RAW264.7 cells, compared to untreated cells.

\section{Effect of mAb COK on apoptotic regulatory proteins}

To examine whether the inhibition of MCF-7 human breast cancer cell growth by anti-GA733-2 mAb could induce apoptosis, the effects of $\mathrm{mAb} \mathrm{b}^{\mathrm{P}} \mathrm{COK}$ treatment on the expression of apoptotic regulatory proteins were determined. We confirmed that treatment of MCF-7 cells with both treatments resulted in reduced expression of anti-apoptotic protein compared to untreated MCF-7 cells. On the contrary, expression levels of pro-apoptotic proteins such as TNF- $\alpha$, Bax, caspase-3, caspase-6, and caspase- 9 increased after treatment with plant-derived mAb COK and RAW264.7 cells (Fig. 4). Moreover, no effect of itself $\mathrm{mAb} \mathrm{b}^{\mathrm{P}} \mathrm{COK}$ on the activity of those proteins on cell apoptosis has been found (data not shown). These data indicate that the $\mathrm{mAb} \mathrm{b}^{\mathrm{P}}$ COK treatment regulates the cell apoptosis proteins on human breast cancer cells.

Effect of $\mathrm{mAb} \mathrm{COK}$ on ganglioside expression

Whether $\mathrm{mAb} \mathrm{COK}$ corresponds to be altered ganglioside expression was determined by HPTLC in six different groups: untreated MCF-7 breast cancer cells (lane 3), untreated RAW264.7 cells (lane 4), MCF-7 breast cancer cells treated with $\mathrm{mAb} \mathrm{b}^{\mathrm{P}}$ COK (lane 5), RAW264.7 cells treated with $\mathrm{mAb} \mathrm{b}^{\mathrm{P}} \mathrm{COK}$ (lane 6 ), MCF-7 breast cancer cells treated with RAW264.7 cells (lane 7), and MCF-7 breast cancer cells treated with both $\mathrm{mAb}^{\mathrm{P}} \mathrm{COK}$ and RAW264.7 cells (lane 8). As shown from HPTLC in Figure 5, the expression level of two other gangliosides, GD1a and GM1, was well detected in cells treated with both treatments (lane 8). No expression of ganglioside GD2 or GT1b was observed in any group. These data suggest that gangliosides GD1a and GM1 are related to $\mathrm{mAb} \mathrm{b}^{\mathrm{P}} \mathrm{COK}$-mediated antiproliferation and apoptotic cell death. 


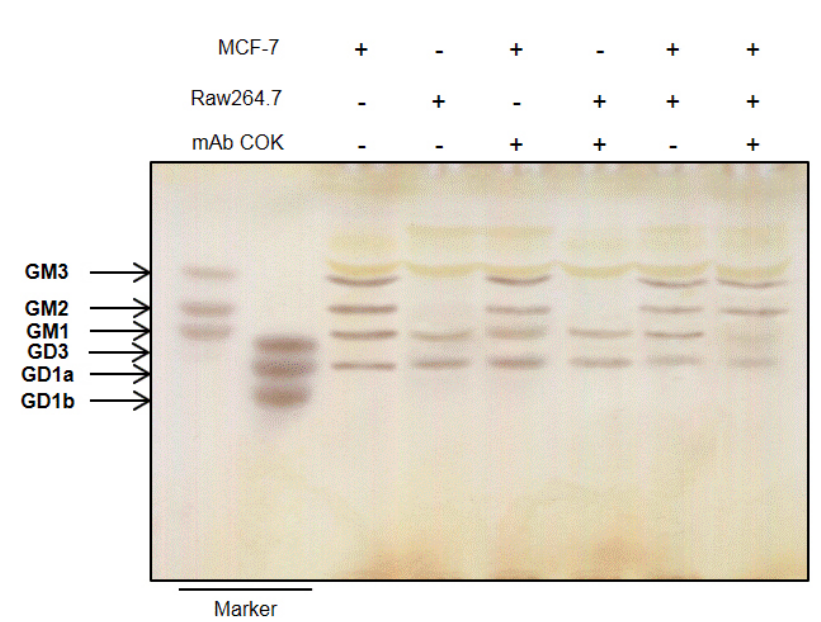

Fig. 5 HPTLC profiles of gangliosides in MCF-7 human breast cancer cells treated with $\mathrm{mAb} \mathrm{b}^{\mathrm{P}} \mathrm{COK}$

Quantitative analysis of extracted glycosphingolipid in MCF-7 human breast cancer cells was performed by resolving them on TLC silica gel plates with chloroform $/$ methanol $/ 0.25 \% \mathrm{CaCl}_{2}$ • $\mathrm{H}_{2} \mathrm{O}$ (50:40:10, v/v). The gangliosides were visualized using resorcinol spraying. Lanes 1 and 2, ganglioside standard markers; lane 3, untreated MCF-7 breast cancer cells; lane 4, untreated RAW264.7 cells; lane 5, MCF-7 breast cancer cells treated with $\mathrm{mAb} \mathrm{b}^{\mathrm{P}} \mathrm{COK}$; lane 6, RAW264.7 cells treated with $\mathrm{mAb} \mathrm{b}^{\mathrm{P}} \mathrm{COK}$; lane 7, MCF-7 breast cancer cells treated with the RAW264.7 cells; lane $8, \mathrm{MCF}-7$ breast cancer cells treated with both treatments

\section{Discussion}

We have previously shown that $\mathrm{mAb} \mathrm{b}^{\mathrm{P}} \mathrm{COK}$ expressed in tobacco plants suppressed cancer cell proliferation and changed the expression pattern of certain gangliosides, such as GD1a and GM1, in colorectal cancer cells (Ryu et al. 2013). A previous study has reported that anti-cancer mAbs produced by transgenic Arabidopsis plants specifically recognize the tumor-associated antigen GA733-2 (Song et al. 2018). In this study, we investigated the bioactivity of $\mathrm{mAb} \mathrm{b}^{\mathrm{P}}$ COK expressed in transgenic Arabidopsis plants on anti-cancer effects and the expression change of glycosphingolipid in breast carcinoma, not colorectal carcinoma.

The GA733-2 has been considered as a major gastrointestinal tumor-associated protein amply expressed in colorectal cancers (Wengi et al. 2009). GA733-2 expression levels are also correlated with intestinal cell proliferation and reversely with differentiation (Zhang et al. 2016). Because of this, GA733-2 has been elucidated as a marvelous candidate for anti-cancer therapeutic agent due to its potential clinical significance (Staib et al. 2001). Ryu et al (2013) have suggested that transgenic plant-derived $\mathrm{mAb} C O K$ and $\mathrm{mAb}{ }^{\mathrm{M}} \mathrm{COK}$ have a remarkable similarity in binding human colorectal cancer cells. The $\mathrm{mAb} \mathrm{COK}$ is as effective as
$\mathrm{mAb} \mathrm{b}^{\mathrm{M}} \mathrm{COK}$ in suppressing the proliferation and tumor growth in in vivo (Ko et al. 2005).

Various chemotherapeutic agents on cancers are regarded as the suppression of cell growth by affecting cell cycle (Alfonso et al. 2009; Xiao et al. 2005). In present study, we investigated the effects of $m A b^{\mathrm{P}}$ COK cell growth suppression and focused on the distribution cells to the various phases of the cell cycle. Treatment of $\mathrm{mAb} \mathrm{b}^{\mathrm{P}} \mathrm{COK}$ to MCF-7 cells resulted in decreased expression on proteins of the first of four phases in cell cycle proteins. Cyclin D1, known to induce cell migration, is essential at diverse phases of the cell cycle (Lapenna and Giordano 2009; Neumeister et al. 2003; Satyanarayana and Kaldis 2009). Immunoblot results suggested that expression levels of proteins, such as CDKs and cyclins, involved in cell cycle regulation, were downregulated in MCF-7 cells after treatment with both $\mathrm{mAb} \mathrm{b}^{\mathrm{P}} \mathrm{COK}$ and RAW264.7 cells in Figure 3. Besides $\mathrm{p} 21$, which functions as a regulator of specific cell cycle, was induced by treatment with both treatments.

Our findings in Figure 4 indicated that the $\mathrm{mAb}^{\mathrm{P}} \mathrm{COK}$ significantly and effectively induces apoptosis of MCF-7 cells. In MCF-7 cells treated with both $\mathrm{mAb}^{\mathrm{P}} \mathrm{COK}$ and RAW264.7 cells, caspase-3, caspase-6, and caspase-9 were significantly activated. Numerous anti-apoptotic and proapoptotic proteins are up- and down-regulated in many colorectal cancer (Coffey et al. 2002; Schoemaker et al. 2002). Zha et al (1996) demonstrated that Bax, an apoptosis regulator, plays a role in the mitochondrial apoptotic process and prevents inhibition of apoptosis in cancer cells. The researchers revealed that the apoptosis regulator also regulates cell death by families of protease enzymes (Seol et al. 2001). Thus, our results suggest that $\mathrm{mAb} \mathrm{b}^{\mathrm{P}} \mathrm{COK}$ efficaciously act as inducing apoptotic mechanisms.

Remarkably, HPTLC analysis indicated that both ganglioside GD1a and GM1 expression were highly decreased in MCF-7 cells treated with $\mathrm{mAb}{ }^{\mathrm{P}} \mathrm{COK}$ and RAW264.7 cells. Shah et al (1996) have previously shown that specific gangliosides have anti-cancer activities on immunoreactions and tumor progression. Interestingly, researchers have showed that specific gangliosides has suppression effects on the metastasis of the colorectal carcinoma in in vivo (Vogel et al. 1996). Hyuga et al (1999) demonstrated that GD1a to regulate metastasis of cancer cells. Therefore, Figure 5 indicated that the ganglioside GD1a and GM1 expression can be decreased in MCF-7 cells treated with Arabidopsis-derived $\mathrm{mAb}^{\mathrm{P}} \mathrm{COK}$.

As the final outcome, we found that the plant-derived $\mathrm{mAb} C \mathrm{COK}$ has various biological activities, including the regulation of gangliosides expression. Further clinical inves- 
tigation is needed to examine the potential capabilities of $\mathrm{mAb} \mathrm{b}^{\mathrm{P}} \mathrm{COK}$ in treating human breast cancer.

\section{Conclusions}

Our current study suggests that the plant-derived anti-cancer monoclonal antibody COK has significant anticancer activities and works by inducing apoptosis, blocking the transition from the G1 to S phase of the cell cycle, and changing the expression pattern of gangliosides GD1a and GM1. Arabidopsis plant might be another alternative plant expression system for the production of anti-cancer therapeutic mAb.

\section{Conflict of Interest}

The authors have no conflict of interest.

\section{Acknowledgments}

This work was supported by the National Research Foundation of Korea (NRF) grant funded by the Korea government (MSIT) [No. 2019R1F1A107], [No. NRF-2017 R1A4A1015594], the KRIBB Research Initiative Program (KGM4251824), and the Next Generation BioGreen 21 program [System and Synthetic Agrobiotech Center, PJ01342101], Republic of Korea. We would like to thank (www.editage.co.kr) for English language editing.

\section{References}

Ai-Haji M, Wicha MS, Benito-Hernandez A, Morrison SJ, Clarke MF (2003) Prospective identification of tumorigenic breast cancer cells. Proc Natl Acad Sci U S A 100:3983-3988

Alfonso LF, Srivenuhopal KS, Arumugam TV, Abbruscato TJ, Weidanz JA, Bhat GJ (2009) Aspirin inhibits camptothecininduced p21CIP1 levels and potentiates apoptosis in human breast cancer cells. Int J Oncol 34:597-608

Ariga T, McDonald MP, Yu RK (2008) Role of ganglioside metabolism in the pathogenesis of Alzheimer's disease-a review. J Lipid Res 49:1157-1175

Baeuerle PA, Gires O (2007) EpCAM (CD326) finding its role in cancer. Br J Cacner 96:417-423

Balzar M, Winter MJ, de Boer CJ, Litvinov SV (1999) The biology of the 17-1A antigen (Ep-CAM). J Mol Med 77:699-712

Basu S, Ma R, Boyle PJ, Mikulla B, Bradley M, Smith B, Basu M, Banerjee S (2004) Apoptosis of human carcinoma cells in the presence of potential anti-cancer drugs: III. Treatment of
Colo-205 and SKBR3 cells with: cis-platin, Tamosifen, Melphalan, Betulinic acid, L-PDMP, L-PPMP, and GD3 ganglioside. Glycoconj J 20:563-577

Bobowski M, Cazet A, Steenackers A, Delannoy P (2012) Role of complex ganglioside in cancer progression. J Carbohyd Chem 37:1-20

Brodzik R, Glogowska M, Bandurska K, Okulicz M, Deka D, Ko $\mathrm{K}$, van der Linden J, Leusen JH, Pogrebnyak N, Golovkin M, Seteplewski Z, Koprowski H (2006) Plant-derived anti-Lewis Y mAb exhibits biological activities for efficient immunotherapy against human cancer cells. Proc Natl Acad Sci U S A 103:8804-8809

Coffey RN, Watson RW, O’Neill AJ, Mc Eleny K, Fitzpatrick JM (2002) Androgen-mediated resistance to apoptosis. Prostate 53:300-309

Dalerba P, Dylla SJ, Park IK, Liu R, Wang X, Cho RW, Hoey T, Gurney A, Huang EH, Simeone DM (2007) Phenotypic characterization of human colorectal cancer stem cells. Proc Natl Acad Sci U S A 104:10158-10163

Daniell H, Streatfield SJ, Wycoff K (2001) Medical molecular farming: production of antibodies, biopharmaceuticals and edible vaccines in plants. Trends Plant Sci 6:219-226

David LN, Michael MC (2005) Lipids. Lehninger Principles of Biochemistry $4^{\text {th }}$ edition. W H Freeman \& Co. p.357

de Boer CJ, van Krieken JH, Janssen-van Rhijn CM, Litvinov SV (1999) Expression of Ep-CAM in normal, regenerating, metaplastic, and neoplastic liver. J Pathol 188:201-206

Eccles SA, Aboagye EO, Ali S, Anderson AS, Armes J, Berditchevski F, Brennan K, Brown NJ, Bryant HE, Bundred NJ, Burchell JM, Campbell AM, Carroll JS, Clarke RB, Coles CE, Cook GJ, Cox A, Curtin NJ, Dekker LV, Silva Idos S, Duffy SW, Easton DF, Eccles DM, Edwards J, Evans D, Fenlon DF, Flanagan JM, Foster C, Gallagher WM, Garcia-Closas M, Gee JM, Gescher AJ, Goh V, Groves AM, Harvey AJ, Harvie M, Hennessy BT, Hiscox S, Holen I, Howell SJ, Howell A, Hubbard G, Hullbert-Williams N, Hunter MS, Jasani B, Jones LJ, Key TJ, Kirwan CC, Kong A, Kunkler IH, Langdon SP, Leach MO, Mann DJ, Marshall JF, Martin L, Martin SG, Macdougall JE, Miles DW, Miller WR, Morris JR, Moss SM, Mullan P, Natrajan R, O’Connor JP, O'Conner R, Palmieri C, Pharoah PD, Rakha EA, Reed E, Robinson SP, Sahai E, Saxton JM, Schimid P, Smalley MJ, Speirs V, Stein R, Stingl J, Streuli CH, Tutt AN, Velikova G, Walker RA, Watson CJ, Williams KJ, Young LS, Thompson AM (2013) Critical research gaps and translational priorities for the successful prevention and treatment of breast cancer. Breast Cancer Res

Fukuda M (1996) Possible roles of tumor-associated carbohydrate antigens. Cancer Res 56:2237-2244

Gomord V, Sourrouille C, Fitchette AC, Bardor M, Pagny S, Lerouge P, Faye L (2004) Production and glycosylation of plant-made pharmaceuticals: the antibodies as a challenge. Plant Biotechnol J 2:83-100

Hyuga S, Yamagata S, Takatsu Y, Nakanishi H, Furukawa K, Yamagata T (1999) Suppression by ganglioside GD1A of 
migration capability, adhesion to vitronectin and metastatic potential of highly metastatic FBJ-LL cells. Int J Cancer 83:685-691

Ji MY, Lee YC, Do S 2nd, Nam SY, Jung KY, Kim HM, Park LK, Choo YK (2000) Developmental patterns of mST3GalIV mRNA expression in the mouse: in situ hybridization using DIG-labeled RNA probes. Arch Pharm Res 23:525-530

Ju EJ, Kwak DH, Lee DM, Kim SM, Kim JS, Kim SM, Choi HG, Jung KY, Lee SU, Do SI, Park YI, Choo YK (2005) Pathophysiological implication of ganglioside GM3 in early mouse embryonic development through apoptosis. Arch Pharm Res 28:1057-1064

Jullien S, Bobowski M, Steenackers A, Le Bourhis X, Delannoy P (2013) How do gangliosides regulate RTKs signaling? Cells 2:751-767

Keller R, Geiges M, Keist R (1990) L-arginine-dependent reactive nitrogen intermediates as mediators of tumor cell killing by activated macrophages. Cancer Res 50:1421-1425

Kim EJ, Park SY, Lee JY, Park JH (2013) Fucoidan present in brown algae induces apoptosis of human colon cancer cells. BMC Gastroenterol

Klimp AH, de Vries EG, Scherphof GL, Daemen T (2002) A potential role of macrophage activation in the treatment of cancer. Crit Rev Oncol Hematol 44:143-161

Ko K, Steplewski Z, Glogowska M, Koprowski H (2005) Inhibition of tumor growth by plant-derived $\mathrm{mAb}$. Proc Natl Acad Sci U S A 102:7026-7030

Koprowski H, Yusibov V (2001) The green revolution: plants as heterologous expression vectors. Vaccine 19:2735-2741

Kudo D, Rayman P, Horton C, Cathcart MK, Bukowski RM, Thornton M, Tannenbaum C, Finke JH (2003) Ganglioside expressed by the renal cell carcinoma cell line SK-RC-45 are involved in tumor-induced apoptosis of T-cells. Cancer Res 63:1676-1683

Lapenna S, Giordano A (2009) Cell cycle kinases as therapeutic targets for cancer. Nat Rev Drug Discov 8:547-566

Lee SM, Ryu JS, Lee JW, Kwak DH, Ko K, Choo YK (2010) Comparison of ganglioside expression between human adipose- and dental pulp-derived stem cell differentiation into osteoblasts. Arch Pharm Res 33:585-591

Li C, Heidt DG, Dalerba P, Burant CF, Zhang L, Adsay V, Wicha M, Clarke MF, Simeone DM (2007) Identification of pancreatic cancer stem cells. Cancer Res 67:1030-1037

Litvinov SV, Velders MP, Bakker HA, Fleuren GJ, Warnaar SO (1994) Ep-CAM: a human epithelial antigen is a hemophilic cell-cell adhesion molecule. J Cell Biol 125:437-446

Ma JK, Drake PM, Christou P (2003) The production of recombinant pharmaceutical proteins in plants. Natl Rev Gent 4:794-805

Ma R, Koulov A, Moulton C, Basu M, Banerjee S, Goodson H, Basu S (2004) Apoptosis of human breast carcinoma cells in the presence of disialosyl ganglioside: II. Treatment of SKBR3 cells with GD3 and GD1b gangliosides. Glycoconj J 20:319-330

Moldenhauer G, Salnikov AV, Lüttgau S, Herr I, Anderl J,
Faulstich H(2012) Therapeutic potential of amanitin-conjugated anti-epithelial cell adhesion molecule monoclonal antibody against pancreatic carcinoma. J Natl Cancer Inst 104:622-634

Münz M, Murr A, Kvesic M, Rau D, Mangold S, Pflanz S, Lumsden J, Volkland J, Riethmüller G (2010) Side-by-side analysis of five clinically tested anti-EpCAM monoclonal antibodies. Cancer Cell Int

Neumeister P, Pixley FJ, Xiong Y, Xie H, Ashton A, Cammer M, Chan A, Symons M, Stanley ER, Pestell RG (2003) Cyclin D1 governs adhesion and motility of macrophages. Mol Biol Cell 14:2005-2015

Paris R, Morales A, Coll O, Sanchez-Reyes A, Garcia-Ruiz C, Fernandez-Checa JC (2002) Ganglioside GD3 sensitizes human hepatoma cells to cancer theraphy. J Biol Chem 277:49870-49876

Regina Todeschini A, Hakomori SI (2008) Functional role of glycosphingolipids and gangliosides in control of cell adhesion, motility, and growth, through glycosynaptic microdomains. Biochim Biophys Acta 1780:421-433

Ryu JS, Lee JT, Lim MU, Hwang MR, Hwang KA, Cho YH, Lee JH, Ko K, Choo YK (2013) Plant-derived mAbs have effective anti-cancer activities by increasing ganglioside expression in colon cancers. Biotechnol Lett 35:2031-2038

Satyanarayana A, Kaldis P (2009) Mammalian cell-cycle regulation: several Cdks, numerous cyclins and diverse compensatory mechanisms. Oncogene 28:2925-2939

Schnell U, Cirnulli V, Giepmans BN (2013) EpCAM: structure and function in health and diases. Biochim Biophys Acta 1828:1989-2001

Schoemaker MH, Ros JE, Homan M, Trautwein C, Liston P, Poelstra K, van Goor H, Jansen PL, Moshage H (2002) Cytokine regulation of pro- and anti-apoptotic genes in rat hepathocytes: NF-kappaB-regulated inhibitor of apoptosis protein 2 (cIAP2) prevents apoptosis. J Hepatol 36:742-750

Seol JG, Park WH, Kim ES, Jung CW, Hyun JM, Lee YY, Kim BK (2001) Potential role of caspase-3 and -9 in arsenic trioxidemediated apoptosis in PCI-1 head and neck cancer cells. Int J Oncol 18:249-255

Shah R, Sabanatham S, Bembridge J, Mearns AJ, Shorrock K (1996) Tumor embolism to LAD during pneumonectomy. A case report. J Cardiovasc Surg (Torino) 37:319-321

Shahrizaila N, Yuki N (2011) Guillain-Barré syndrome animal model: the first proof of molecular mimicry in human autoimmune disorder. J Biomed Biothenol

Siegel R, Naishadham D, Jemal A (2012) Cancer statistics, 2012. CA Cancer J Clin 62:10-29

Song I, Kang Y, Lee YK, Myung SC, Ko K (2018) Endoplasmic reticulum retention motif fused to recombinant anti-cancer monoclonal antibody (mAb) CO17-1A affects mAb expression and plant stress response. PLoS One

Spizzo G, Fong D, Wurm M (2011) EpCAM expression in primary tumor tissue and metastasis: an immunohistochemical analysis. J Clin Pathol 64:415-420

Staib L, Birebent B, Somasundaram R, Purev E, Braumüller H, Leese C, Küttner N, Li W, Zhu D, Diao J, Wunner W, Speicher 
D, Beger HG, Song H, Herlyn D (2001) Immunogenicity of recombinant GA733-2E antigen (CO17-1A, EGP, KS1-4, KSA, Ep-CAM) in gastro-intestinal carcinoma patients. Int J Cancer 92:79-87

Strnad J, Hamilton AE, Beavers LS, Gamboa GC, Apelgren LD, Taber LD, Sportsman JR, Bumol TF, Sharp JD, Gadski RA (1989) Molecular cloning and characterization of a human adenocarcinoma/epithelial cell surface antigen complementary DNA. Cancer Res. 49:314-317

Svennerholm L (1980) Ganglioside designation. Adv Exp Med Biol

Trizpis M, McLaughlin PM, de Leji LM, Harmsen MC (2007) Epithelial cell adhesion molecule: more than a carcinoma marker and adhesion molecule. Am J Pathol 171:386-395

Verch T, Yusibov V, Koprowski H (1998) Expression and assembly of a full-length monoclonal antibody in plants using a plant virus vector. J Immunol Methods 220:69-75

Vogel CA, Galmiche MC, Westermann P, Sun Lin-Quan, Pèlegrin A, Silvio F, Delaloye AB, Slosman DO, Mach Jean-Pierre, Buchegger F (1996) Carcinoembryonic antigen expression, antibody localisation and immunophotodetection of human colon cancer liver metastases in nude mice: A model for radioimmunotherapy. Int J Cancer 67:294-302

Wenqi D, Li W, Shanshan C, Bei C, Yafei Z, Feihu B, Jie L,
Daiming F (2009) EpCAM is overexpressed in gastric cancer and its downregulation suppresses proliferation of gastric cancer. J Cancer Res Clin Oncol 135:1277-1285

Went PT, Lugli A, Meier S, Bundi M, Mirlacher M, Sauter G, Dirnhofer S (2004) Frequent EpCAM protein expression in human carcinomas. Hum Pathol 35:122-128

Xiao D, Herman-Antosiewicz A, Antosiewicz J, Xiao H, Brisson M, Lazo JS, Singh SV (2005) Diallyl trisulfide-induced $\mathrm{G}(2)-\mathrm{M}$ phase cell cycle arrest in human prostate cancer cells is caused by reactive oxygen species-dependent destruction and hyperphosphorylation of Cds 25 C. Oncogene 24:6256-6268

Yamashita T, Wada R, Sasaki T, Deng C, Bierfreund U, Sandhoff K, Proia RL (1999) A vital role for glycosphingolipid synthesis during development and differentiation. Proc Natl Acad Sci U S A 96:9142-9147

Zha H, Aimé-Sempé C, Sato T, Reed JC (1996) Proapoptotic protein Bax heterodimerizes with Bcl-2 and homodimerizes with Bax via a novel domain (BH3) distinct from $\mathrm{BH} 1$ and BH2. J Biol Chem 271:7440-7444

Zhang ZY, Lu YX, Zhang ZY, Chang YY, Zheng L, Yuan L, Zhang F, Hu YH, Zhang WJ, Li XN (2016) Loss of TINCR expression promotes proliferation, metastasis through activating EpCAM cleavage in colorectal cancer. Oncotarget 7:22639-22649 